\title{
Pengaruh Model Ajir dan Pemangkasan Tunas Lateral Terhadap Pertumbuhan dan Hasil Tanaman Tomat (Lycopersicum esculentum, Mill.) Cv. Lentana
}

\author{
Florensia Maria Gradiana Nabuana ${ }^{\mathrm{a}}$ \\ ${ }^{a}$ Fakultas Pertanian, Universitas Timor, Kefamenanu, TTU - NTT, 85613, Indonesia
}

\section{Article Info}

\section{Article history:}

Received 10 Agustus 2015

Received in revised form 20 Januari 2016

Accepted 19 Februari 2016

\section{Keywords:}

Model Ajir

Pemangkasan Tunas Latera

Tomat

\begin{abstract}
Abstrak
Tomat merupakan salah satu komoditas yang bernilai ekonomis yang sangat tinggi. Dalam usaha untuk memperoleh hasil yang tinggi maka diperlukan teknik budidaya yang tepat seperti penggunaan model ajir yang tepat serta dilakukan pemangkasan tunas lateral. Penelitian ini bertujuan mengetahui pengaruh model ajir dan pemangkasan tunas lateral terhadap pertumbuhan dan hasil tomat varietas Lentana, dilaksanakan bulan Februari - Mei 2015 menggunakan Rancangan Acak Kelompok (RAK). Faktor pertama adalah model ajir yang terdiri dari tiga aras yaitu ajir tunggal, ajir pagar dan ajir segi tiga. Faktor kedua adalah pemangkasan tunas lateral yang terdiri dari dua aras yaitu tanpa pangkas dan pangkas. Hasil penelitian menunjukkan interaksi antara model ajir dan pemangkasan tunas lateral tidak terjadi pada semua parameter yang diamati. Model ajir hanya berpengaruh nyata pada parameter diameter batang 42 HST sedangkan pemangkasan tunas lateral tidak berpengaruh nyata pada semua parameter. Pemberian ajir model pagar memberikan hasil tertinggi yakn 41,80 t/ha dibandingkan ajir model tunggal dan segitiga. Perlakuan tanpa pangkas memberikan hasil tertinggi yaitu 39,62 t/ha dibandingkan perlakuan pemangkasan tunas lateral. (02016 dipublikasikan oleh Savana Cendana.
\end{abstract}

\section{Pendahuluan}

Tomat (Lycopersicum esculentum, Mill.) merupakan salah satu komoditas hortikultura yang penting yaitu sebagai tanaman sayuran. Tomat mempunyai manfaat dan khasiat sangat banyak dan hampir dikonsumsi setiap hari, terutama oleh penggemar saus tomat, jus tomat dan sambal tomat, juga berkhasiat untuk membantu proses penyembuhan sariawan dan rabun ayam, selain itu tomat sangat bermanfaat bagi tubuh karena mengandung vitamin dan mineral yang diperlukan untuk pertumbuhan dan kesehatan (Fitriani, 2012). Tomat memilik komposisi zat yang cukup lengkap, komposisi yang paling menonjol adalah vitamin A dan vitamin $\mathrm{C}$ terutama pada daging buahnya, nilai gizi buah toma segar (tiap $100 \mathrm{~g}$ buah) mengandung Protein $1 \mathrm{~g}$, Karbohidrat 4,2 g, Lemak 0,3 g, Vitamin A 1500 SI, Vitamin B10,06 mg, Vitamin C $40 \mathrm{mg}$ (Susanto dan Saneto, 1994)

Tanaman tomat merupakan salah satu komoditas yang bernilai ekonomis yang sangat tinggi, permintaan pasarnya terus meningkat baik di pasar loka maupun untuk ekspor sedangkan suplainya belum tercukupi, oleh karena itu kesempatan yang cukup besar untuk memanfaatkan peluang usaha pada tomat (Hanindita, 2008)

Produksi tomat di Kabupaten Timor Tengah Utara (TTU), dari 2007- 2010 berfluktuasi dan sempat meningkat tinggi pada tahun 2009 yang mencapai 259 ton tetapi menurun pada tahun 2010 yakni hanya 99 ton. Secara nasiona produksi tomat pada tahun yang sama sebesar 891.616 ton pada luas panen 61.154 ha dengan produktivitasnya sebesar 14,58 t/ha (BPS, 2014) Produktivitas ini jauh lebih rendah dibandingkan dengan potensi produksi tomat varietas Lentana yang dapat mencapai 40-60 t/ha.

Setiawan dan Trisnawati (1999) menyatakan bahwa untuk memperoleh hasil tomat yang baik maka tanaman perlu diberi ajir sebagai tempat merambat. Keuntungan yang diperoleh dalam penggunaan ajir adalah mudah dirawat, bebas mendapatkan penyinaran matahari yang cukup, bunga tidak rusak, buah tidak kotor dan terhindar dari serangan hama. Sebelumnya Rukmana (1994) juga menyatakan bahwa keuntungan pemasangan ajir atau lanjaran yaitu tanaman tumbuh tegak, memperbaiki penyebaran daun dan tunas, mempermudah penyemprotan pestisida maupun penyiangan gulma dan pemupukan. Selain penggunaan ajir untuk mendapatkan hasil tomat yang baik maka perlu dilakukan perempelan atau pemangkasan tunas. Pracaya (1998) mengemukakan bahwa keuntungan dari perempelan atau pemangkasan tunas adalah tanaman tomat cepat tinggi dan berbunga, buah cepat lebih besar, lebih cepat masak, mudah dipanen dan lebih bersih, tidak terkena tanah dan harga jual lebih tinggi, pemangkasan tunas lateral juga dapat mempercepat proses fotosintesis.

Permasalahan yang melatar-belakangi penelitian ini adalah belum diketahu pengaruh serta model ajir dan pemangkasan tunas lateral yang tepat, yang dapa meningkatkan pertumbuhan dan hasil tanaman tomat varietas Lentana Penelitian ini bertujuan mengetahui pengaruh model ajir dan pemangkasan tunas lateral terhadap pertumbuhan dan hasil tomat varietas Lentana.

\section{Metode}

\subsection{Waktu dan Tempat}

Penelitian ini telah dilaksanakan pada bulan Februari - Mei tahun 2015, di Oepote Km.9, Kelurahan Sasi, Kecamatan Kota, Kabupaten Timor Tengah Utara, Provinsi Nusa Tenggara Timur.

\subsection{Rancangan Percobaan}

Penelitian ini dilaksanakan dalam bentuk percobaan yang dirancang dengan menggunakan Rancangan Acak Kelompok (RAK) faktorial 3 x 2 Faktor pertama adalah model ajir (A) yang terdiri dari tiga aras yaitu ajir tunggal $\left(a_{1}\right)$, ajir pagar $\left(a_{2}\right)$ dan ajir segi tiga $\left(a_{3}\right)$. Faktor kedua adalah pemangkasan tunas lateral $(\mathrm{P})$ yang terdiri dari dua aras yaitu tanpa pangkas $\left(\mathrm{p}_{0}\right)$ dan pangkas $\left(\mathrm{p}_{1}\right)$. Kombinasi perlakuannya adalah $\mathrm{a}_{1} \mathrm{p}_{0} \mathrm{a}_{1} \mathrm{p}_{1}, \mathrm{a}_{2} \mathrm{p}_{0}, \mathrm{a}_{2} \mathrm{p}_{1}, \mathrm{a}_{3} \mathrm{p}_{0}$ dan $\mathrm{a}_{3} \mathrm{p}_{1}$. Setiap kombinasi perlakuan diulang tiga kali sehingga terdapat 18 unit percobaan.

\subsection{Pelaksanaan Penelitian}

a. Persiapan benih

Benih yang digunakan dalam penelitian adalah benih tomat F1 varietas Lentana yang dibeli dari toko sarana produksi pertanian sebanyak tiga bungkus. b. Pengolahan Tanah

Pengolahan lahan dilakukan dua tahap yaitu pembersihan lahan, dilanjutkan dengan pencangkulan tanah sedalam $30 \mathrm{~cm}$ setelah itu dibiarkan selama satu minggu. Pengolahan tahap kedua dilakukan dengan cara menghancurkan bongkahan tanah yang besar kemudian dilanjutkan dengan pembuatan bedeng dengan ukuran perpetak panjang $290 \mathrm{~cm}$, lebar $180 \mathrm{~cm}$, jarak petak $30 \mathrm{~cm}$ dan jarak antara blok $50 \mathrm{~cm}$, tiap blok terdiri dari 6 petak Pada setiap blok, petak, tanaman sampel dan tanaman korban diberikan label menggunakan tiang bambu dan papan.

c. Pembibitan

Benih tomat disemaikan terlebih dahulu dan tanah yang dijadikan persemaian dicangkul hingga menjadi gembur, kemudian digali sedalam $20 \mathrm{~cm}$, bedengan persemaian diberi atap plastik, sesudah bibit tomat tumbuh 2 minggu, bibit selanjutnya dipindahkan ke polybag ukuran $10 \mathrm{~cm}$. Bibit yang disiapkan sebanyak 950 tanaman (kebutuhan 720 tanaman dan 230 bibit cadangan).

d. Penanaman

Pembuatan lubang tanam berbentuk segi empat dilakukan 1 minggu sebelum tanam dengan ukuran panjang $20 \mathrm{~cm}$, lebar $15 \mathrm{~cm}$, jarak tanaman $30 \times$ $40 \mathrm{~cm}$. Penanaman dilakukan pada waktu bibit berumur 29 hari dan telah memiliki 4-5 helai daun. Tiap lubang ditanam 1 bibit. Sebelum ditanam lubang tanam disiram terlebih dahulu dan pada saat penanaman plastik atau polibag dikeluarkan secara hati-hati, kemudian dimasukkan ke dalam lubang tanam, penanaman dilakukan pada sore hari. Jumlah tanaman dalam setiap anak petak adalah 40 tanaman dengan jumlah keseluruhan 720 tanaman.

e. Penyiraman

Penyiraman dilakukan sejak benih ditaburkan ke bedeng persemaian sampai panen. Penyiraman dilakukan 2 kali sehari yaitu pada pagi dan sore hari, penyiraman dilakukan dengan menggunakan ember.

f. Pemberian Ajir

Pemberian ajir dilakukan setelah tanaman tomat berumur 10 hari dengan ketinggian ajir $125 \mathrm{~cm}$, ajir tunggal berupa kayu yang telah dipotong, lalu ditancapkan tegak lurus dekat setiap tanaman, ajir kaki dua (segitiga) mirip dengan ajir tunggal hanya pada setiap ujung atas ajir diikat dengan tali rafia, dan ajir model pagar ditancapkan belahan bambu pada setiap tanaman dan posisinya tegak kemudian antara ajir dihubungkan dengan bambu sehingga kelihatan seperti pagar ajir.

g. Penyulaman

Penyulaman dilakukan dengan menggantikan bibit yang rusak, mati, kurang sehat pertumbuhannya. Bibit sulaman disiapkan dalam polibag yan tersedia dan bibit penyulaman diambil dari bibit persemaian yang sudah disediakan dan umur yang sama. Penyulaman dilakukan pada saat tanaman berumur 10 hari HST dengan menggantikan 15 tanaman yang rusak/mati.

h. Penyiangan

Penyiangan dilakukan terhadap gulma yang tumbuh disekitar tanaman.

i. Pemupukan

Pemupukan dilakukan dengan menggunakan hijauan daun (gamal) mentah, diberi 1 minggu sebelum tanam dengan takaran $1 \mathrm{~kg}$ per lubang tanam.

j. Pengendalian Hama

Pengendalian hama dilakukan dengan memetik dan membuang buah tomat yang terserang hama ulat Heliotis Armigera yang awal mula mengebor buah sambil memakannya sehingga terjadi kerusakan buah. Buah yang di serang hama ulat 10 buah dari 5 tanaman. 


\section{k. Pemangkasan}

Pemangkasan dilakukan saat $35 \mathrm{HST}$, dan dipangkas pada pagi hari agar luka bekas pemangkasan cepat kering, dengan cara ujung tunas dipegang dengan tangan yang bersih, lalu tunas tersebut dipangkas menggunakan gunting. 1. Panen

Panen dilakukan saat buah tomat telah masak dan berumur 70 HST dengan cara dipetik. Pemanenan dilakukan 3 kali dengan interval waktu 1 minggu.

\subsection{Parameter Pengamatan}

a. Tinggi Tanaman $(\mathrm{cm})$

Tinggi tanaman diukur dari pangkal batang sampai ujung daun paling tinggi, pengukuran menggunakan pengaris centimeter. Pengukuran dilakukan pada lima tanaman sampel saat berumur 14 HST, 28 HST dan 42 HST.

b. Diameter Batang (mm)

Pengukuran diameter batang dilakukan dengan menggunakan jangka sorong dengan cara menjepit pada bagian batang $(1 \mathrm{~cm}$ di atas pangkal batang) dari lima tanaman sampel pada setiap petak. Pengukuran dilakukan pada saat tanaman berumur 14 HST, 28 HST dan 42 HST.

c. Luas Daun $\left(\mathrm{cm}^{2}\right)$

Luas daun diukur pada saat tanaman mencapai pertumbuhan vegetatif maksimum (73 HST). Pengukuran luas daun dilakukan menggunakan metode fotografi dengan cara mengambil semua daun pada tiga tanaman korban pada tiap petak, kemudian daun dipotret menggunakan kamera digital. Luas area daun kemudian dihitung menggunakan program ImageJ versi 1.410

\section{d. Diameter Buah (mm)}

Pengukuran diameter buah dilakukan dengan menggunakan jangka sorong dengan cara menjepit pada bagian buah yang terbesar. Buah yang diukur adalah semua buah yang dipanen dari lima tanaman sampel pada setiap petak kemudian dirata-ratakan. Pengukuran dilakukan setiap kali panen kemudian dirata-ratakan untuk memperoleh ukuran diameter buah.

e. Berat Per Buah $(\mathrm{g})$

Berat per buah diukur dengan cara menimbang buah tomat menggunakan timbangan analitik. Buah yang ditimbang adalah semua buah yang dipanen dari setiap tanaman sampel pada semua petak kemudian dirata-ratakan dengan cara berat total dibagi dengan jumlah buah. Pengukuran dilakukan setiap kali panen kemudian dirata-ratakan untuk memperoleh ukuran berat per buah.

f. Jumlah Buah Per Tanaman

Buah yang dipanen dari lima tanaman sampel dihitung kemudian dirataratakan. Perhitungan dilakukan setiap kali panen kemudian dijumlahkan untuk mendapatkan jumlah buah tomat per tanaman.

\section{g. Berat Buah Per Tanaman $(\mathrm{kg})$}

Berat buah per tanaman diukur dengan cara menimbang buah tomat menggunakan timbangan analitik. Buah yang ditimbang adalah semua buah yang dipanen dari lima tanaman sampel pada setiap petak kemudian dirataratakan dengan cara berat total dibagi dengan jumlah tanaman sampel. Pengukuran dilakukan setiap kali panen kemudian dijumlahkan untuk memperoleh ukuran berat buah per tanaman.

h. Jumlah Buah Per Petak

Buah yang dipanen dari semua tanaman setiap petak dihitung. Perhitungan dilakukan setiap kali panen kemudian dijumlahkan untuk mendapatkan jumlah buah per petak total panen. Hasil perhitungan dikonversi untuk luas lahan satu hektar.

i. Berat Buah Per Petak (t/ha)

Berat buah per petak diukur dengan cara menimbang buah tomat menggunakan timbangan gantung. Buah yang ditimbang adalah semua buah yang dipanen dari setiap petak. Pengukuran dilakukan setiap kali panen kemudian dijumlahkan untuk memperoleh ukuran berat buah per petak total panen kemudian dikonversi ke t/ha.

j. Berat Segar Berangkasan (t/ha)

Berat segar berangkasan diukur dengan cara menimbang berangkasan semua tanaman dalam setiap petak yang telah dipanen kemudian dikonversikan ke satuan t/ha. Pengukuran menggunakan timbangan duduk.

k. Berat Kering Berangkasan(t/ha)

Berat kering berangkasan diukur dengan cara menimbang berangkasan semua tanaman dalam setiap petak yang telah dipanen dan dijemur selama satu minggu kemudian dikonversikan ke satuan t/ha. Pengukuran menggunakan timbangan duduk.

1. Indeks Panen (\%)

Indeks panen dihitung dengan cara membandingkan berat bagian tanaman yang bernilai ekonomis dengan berat bagian seluruh tanaman kemudian dikonversikan ke satuan \%. Indeks panen dihitung dengan rumus:

$$
\mathrm{IP}=\frac{\mathrm{A}}{\mathrm{A}+\mathrm{B}} \mathrm{X} 100 \%
$$

Keterangan

IP : Indeks Panen (\%)

A : Berat Buah Per Petak (t/ha)

B : Berat Segar Brangkasan (t/ha)
2.5 Analisis Data

Data hasil pengamatan kemudian dianalisis dengan menggunakan sidik ragam (Anova) Rancangan Acak Kelompok (RAK). Rata-rata perlakuan selanjutnya diuji lanjut dengan menggunakan Duncan Multiple Range Test (DMRT) dengan tingkat signifikasi 5\% sesuai petunjuk Nasir (2003). Analisis data menggunakan program SAS 9.1 .

\section{Hasil dan Pembahasan}

Interaksi antara model ajir dan pemangkasan tunas lateral tidak terjadi pada semua parameter yang diamati. Model ajir hanya berpengaruh nyata pada parameter diameter batang 42 HST sedangkan pemangkasan tunas lateral tidak berpengaruh nyata pada semua parameter.

\subsection{Tinggi Tanaman}

Tanaman semakin bertambah tinggi pada pengamatan awal hingga pengamatan terakhir. Hasil sidik ragam (anova) menunjukkan bahwa tidak terjadi interaksi antara model ajir dan pemangkasan tunas lateral pada tinggi tanaman.

Tabel 1. Tinggi Tanaman $(\mathrm{cm})$

\begin{tabular}{ccccc}
\hline Waktu & Model & \multicolumn{2}{c}{ Pemangkasan Tunas Lateral } & \multirow{2}{*}{ Rerata } \\
\cline { 2 - 4 } Pengamatan & Ajir & Tanpa Pangkas & Pangkas & \\
\hline \multirow{4}{*}{14 HST } & Tunggal & 14,1 & 13,4 & $13,7 \mathrm{a}$ \\
& Pagar & 13,3 & 13,7 & $13,5 \mathrm{a}$ \\
& Segitiga & 14,2 & 14,8 & $14,5 \mathrm{a}$ \\
\cline { 2 - 4 } & Rerata & 13,9 & 14,0 & \\
\hline \multirow{4}{*}{28 HST } & Tunggal & 44,1 & 44,1 & $44,1 \mathrm{a}$ \\
& Pagar & 42,4 & 44,3 & $43,4 \mathrm{a}$ \\
& Segitiga & 47,4 & 51,7 & $49,6 \mathrm{a}$ \\
\cline { 2 - 4 } $42 \mathrm{HST}$ & Rerata & 44,7 & 46,7 & \\
& Tunggal & $86,7 \mathrm{a}$ & $89,6 \mathrm{a}$ & $88,1 \mathrm{a}$ \\
& Pagar & $89,0 \mathrm{a}$ & $85,5 \mathrm{a}$ & $87,3 \mathrm{a}$ \\
& Segitiga & $85,3 \mathrm{a}$ & $92,5 \mathrm{a}$ & $88,9 \mathrm{a}$ \\
\cline { 2 - 4 } & Rerata & $87,0 \mathrm{a}$ & $89,2 \mathrm{a}$ & $(-)$ \\
\hline
\end{tabular}

Keterangan: Angka pada baris dan kolom yang diikuti dengan huruf yang sama tidak berbeda nyata menurut uji DMRT $\alpha$ 5\%. ( - ) : Tidak terjadi interaksi antar faktor

Model ajir tidak berpengaruh nyata pada tinggi tanaman setiap waktu pengamatan tetapi data Tabel 1. menunjukkan bahwa tanaman yang diberikan ajir bentuk segitiga cenderung lebih tinggi dan tanaman yang diberikan ajir model pagar paling pendek saat pengamatan awal hingga pengamatan terakhir. Pemangkasan tunas lateral tidak berpengaruh nyata pada tinggi tanaman saat 42 HST, tetapi dapat diketahui bahwa perlakuan pangkas memberikan tanaman yang cenderung lebih tinggi dibandingkan perlakuan tanpa pangkas.

\subsection{Diameter Batang}

Batang tanaman semakin bertambah besar pada pengamatan awal hingga pengamatan terakhir. Hasil sidik ragam (anova) menunjukkan bahwa terjadi interaksi antar model ajir dan pemangkasan tunas lateral pada parameter diameter batang pada waktu pengamatan 42 HST.

Model ajir tidak berpengaruh nyata pada diameter batang 14 HST dan 28 HST tetapi data Tabel 2. menunjukkan bahwa batang tanaman yang diberikan ajir tunggal cenderung lebih besar sedangkan batang tanaman yang diberikan ajir pagar selalu lebih kecil. Pada pengamatan 42 HST model ajir berpengaruh nyata pada diameter batang dimana batang tanaman yang diberikan ajir mode pagar paling besar dan berbeda nyata dengan diameter batang tanaman yang diberikan ajir model segitiga tetapi tidak berbeda nyata dengan model ajir tunggal. Pemangkasan tunas lateral tidak berpengaruh nyata pada diameter batang waktu pengamatan 42 HST tetapi batang tanaman yang dipangkas cenderung lebih besar dibanding tanpa pangkas.

\section{Tabel 2. Diameter Batang (cm)}

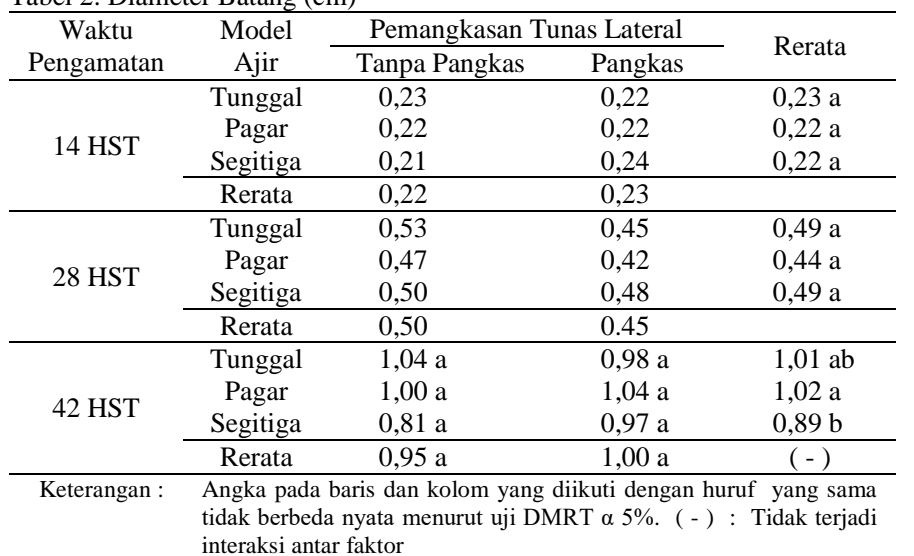




\subsection{Luas Daun}

Hasil sidik ragam (anova) menunjukkan bahwa tidak terjadi interaksi antar model ajir dan pemangkasan tunas lateral pada parameter luas daun.

Model ajir tidak berpengaruh nyata terhadap luas daun tetapi data pada Tabel 3. menunjukkan bahwa daun tanaman yang diberikan ajir tunggal cenderung lebih luas sedangkan tanaman yang diberikan ajir pagar memiliki daun yang paling sempit. Pemangkasan tunas lateral juga tidak berpengaruh nyata terhadap luas daun tetapi tanaman yang tidak dipangkas memiliki daun yang cenderung lebih luas dibanding tanaman yang dipangkas.

Tabel 3. Luas Daun $\left(\mathrm{cm}^{2}\right)$

\begin{tabular}{cccc}
\hline \multirow{2}{*}{ Model Ajir } & \multicolumn{2}{c}{ Pemangkasan Tunas Lateral } & \multirow{2}{*}{ Rerata } \\
\cline { 2 - 3 } & Tanpa Pangkas & Pangkas & \\
\hline Tunggal & $1613,00 \mathrm{a}$ & $1341,33 \mathrm{a}$ & $1477,16 \mathrm{a}$ \\
Pagar & $1267,12 \mathrm{a}$ & $1357,80 \mathrm{a}$ & $1312,46 \mathrm{a}$ \\
Segitiga & $1441,73 \mathrm{a}$ & $1370,64 \mathrm{a}$ & $1406,18 \mathrm{a}$ \\
\hline Rerata & $1440,62 \mathrm{a}$ & $1356,59 \mathrm{a}$ & $(-)$ \\
\hline Keterangan : & Angka pada baris dan kolom yang diikuti dengan huruf yang sama \\
& tidak berbeda nyata menurut uji DMRT $\alpha \%$ 5\%. ( - ) : Tidak terjadi \\
& interaksi antar faktor
\end{tabular}

\subsection{Diameter Buah}

Hasil sidik ragam (anova) menunjukkan bahwa tidak terjadi interaksi antar model ajir dan pemangkasan tunas lateral pada parameter diameter buah.

Model ajir tidak berpengaruh nyata terhadap diameter buah tetapi data pada Tabel 4. menunjukkan bahwa buah dari tanaman yang diberikan ajir pagar cenderung lebih besar sedangkan buah paling kecil adalah buah dari tanaman yang diberikan ajir segitiga. Pemangkasan tunas lateral juga tidak berpengaruh nyata pada diameter buah dan buah pada tanaman yang tidak dipangkas dan yang dipangkas cenderung memiliki diameter yang sama besar.

Tabel 4. Diameter Buah $(\mathrm{cm})$

\begin{tabular}{|c|c|c|c|}
\hline \multirow{2}{*}{ Model Ajir } & \multicolumn{2}{|c|}{ Pemangkasan Tunas Lateral } & \multirow{2}{*}{ Rerata } \\
\hline & Tanpa Pangkas & Pangkas & \\
\hline Tunggal & $4,21 \mathrm{a}$ & $4,22 \mathrm{a}$ & $4,22 \mathrm{a}$ \\
\hline Pagar & $4,21 \mathrm{a}$ & $4,31 \mathrm{a}$ & $4,26 \mathrm{a}$ \\
\hline Segitiga & $4,24 \mathrm{a}$ & $4,12 \mathrm{a}$ & $4,18 \mathrm{a}$ \\
\hline Rerata & $4,22 \mathrm{a}$ & $4,22 \mathrm{a}$ & $(-)$ \\
\hline Keterangan : & $\begin{array}{l}\text { Angka pada baris da } \\
\text { tidak berbeda nyata } r \\
\text { interaksi antar faktor }\end{array}$ & $\begin{array}{l}\text { ang diiku } \\
\text { i DMRT }\end{array}$ & $\begin{array}{l}\text { uf yang sama } \\
\text { Tidak terjadi }\end{array}$ \\
\hline
\end{tabular}

\subsection{Berat Per Buah}

Hasil sidik ragam (anova) menunjukkan bahwa tidak terjadi interaksi antar model ajir dan pemangkasan tunas lateral pada parameter berat per buah.

Model ajir tidak berpengaruh nyata terhadap berat per buah tetapi data pada Tabel 5. menunjukkan bahwa buah dari tanaman yang diberikan ajir segitiga cenderung lebih berat sedangkan buah paling ringan adalah buah dari tanaman yang diberikan ajir pagar. Pemangkasan tunas lateral juga tidak berpengaruh nyata pada berat per buah dan buah pada tanaman yang tidak dipangkas cenderung lebih berat dibandingkan yang dipangkas.

Tabel 5. Berat Per Buah (g)

\begin{tabular}{cccc}
\hline \multirow{2}{*}{ Model Ajir } & \multicolumn{2}{c}{ Pemangkasan Tunas Lateral } & \multirow{2}{*}{ Rerata } \\
\cline { 2 - 3 } & Tanpa Pangkas & Pangkas & \\
\hline Tunggal & $37,1 \mathrm{a}$ & $35,7 \mathrm{a}$ & $36,4 \mathrm{a}$ \\
Pagar & $35,2 \mathrm{a}$ & $35,7 \mathrm{a}$ & $35,5 \mathrm{a}$ \\
Segitiga & $39,9 \mathrm{a}$ & $35,5 \mathrm{a}$ & $37,7 \mathrm{a}$ \\
\hline Rerata & $37,4 \mathrm{a}$ & $35,6 \mathrm{a}$ & $(-)$ \\
\hline Keterangan : & Angka pada baris dan kolom yang diikuti dengan huruf yang sama \\
& tidak berbeda nyata menurut uji DMRT $\alpha$ 5\%. ( - ) : Tidak terjadi \\
& interaksi antar faktor
\end{tabular}

\subsection{Jumlah Buah Per Tanaman}

Hasil sidik ragam (anova) menunjukkan bahwa tidak terjadi interaksi antar model ajir dan pemangkasan tunas lateral pada parameter jumlah buah per tanaman.

$\underline{\text { Tabel 6. Jumlah Buah Per Tanaman }}$

\begin{tabular}{|c|c|c|c|}
\hline \multirow{2}{*}{ Model Ajir } & \multicolumn{2}{|c|}{ Pemangkasan Tunas Lateral } & \multirow{2}{*}{ Rerata } \\
\hline & Tanpa Pangkas & Pangkas & \\
\hline Tunggal & $37 \mathrm{a}$ & $34 \mathrm{a}$ & $36 \mathrm{a}$ \\
\hline Pagar & $33 \mathrm{a}$ & $31 \mathrm{a}$ & $32 \mathrm{a}$ \\
\hline Segitiga & $33 \mathrm{a}$ & $33 \mathrm{a}$ & $33 \mathrm{a}$ \\
\hline Rerata & $34 \mathrm{a}$ & $33 \mathrm{a}$ & $(-)$ \\
\hline Keterangan : & $\begin{array}{l}\text { Angka pada baris dan kolo } \\
\text { tidak berbeda nyata menur } \\
\text { interaksi antar faktor }\end{array}$ & $\begin{array}{l}\text { kuti deng } \\
\text { T } \alpha 5 \% \text {. }\end{array}$ & $\begin{array}{l}\text { yang san } \\
\text { idak terja }\end{array}$ \\
\hline
\end{tabular}

Model ajir tidak berpengaruh nyata terhadap jumlah buah per tanaman tetapi data pada Tabel 6. menunjukkan bahwa buah dari tanaman yang diberikan ajir tunggal cenderung lebih banyak sedangkan buah paling sedikit adalah buah dari tanaman yang diberikan ajir pagar. Pemangkasan tunas lateral juga tidak berpengaruh nyata pada jumlah buah per tanaman dan buah pada tanaman yang tidak dipangkas cenderung lebih banyak dibandingkan yang dipangkas.

\subsection{Berat Buah Per Tanaman}

Hasil sidik ragam (anova) menunjukkan bahwa tidak terjadi interaksi antar model ajir dan pemangkasan tunas lateral pada parameter berat buah per tanaman.

\section{Tabel 7. Berat Buah Per Tanaman (g)}

\begin{tabular}{|c|c|c|c|}
\hline \multirow{2}{*}{ Model Ajir } & \multicolumn{2}{|c|}{ Pemangkasan Tunas Lateral } & \multirow{2}{*}{ Rerata } \\
\hline & Tanpa Pangkas & Pangkas & \\
\hline Tunggal & $1338,1 \mathrm{a}$ & $1220,7 \mathrm{a}$ & $1279,4 \mathrm{a}$ \\
\hline Pagar & $1153,4 \mathrm{a}$ & $1101,4 \mathrm{a}$ & $1127,4 \mathrm{a}$ \\
\hline Segitiga & $1283,2 \mathrm{a}$ & $1187,2 \mathrm{a}$ & $1235,2 \mathrm{a}$ \\
\hline Rerata & $1258,2 \mathrm{a}$ & $1169,8 \mathrm{a}$ & $(-)$ \\
\hline rangan & $\begin{array}{l}\text { Angka pada baris dan kol } \\
\text { tidak berbeda nyata menu } \\
\text { interaksi antar faktor }\end{array}$ & $\begin{array}{l}\text { diikuti deng } \\
\text { IRT } \alpha 5 \% \text {. }\end{array}$ & $\begin{array}{l}\text { yang sama } \\
\text { Tidak terjadi }\end{array}$ \\
\hline
\end{tabular}

Model ajir tidak berpengaruh nyata terhadap berat buah per tanaman tetapi data pada Tabel 7. menunjukkan bahwa buah dari tanaman yang diberikan ajir tunggal cenderung lebih berat sedangkan buah paling ringan adalah buah dari tanaman yang diberikan ajir pagar. Pemangkasan tunas lateral juga tidak berpengaruh nyata pada berat buah per tanaman dan buah pada tanaman yang tidak dipangkas cenderung lebih berat dibandingkan yang dipangkas.

\subsection{Jumlah Buah Per Petak}

Hasil sidik ragam (anova) menunjukkan bahwa tidak terjadi interaksi antar model ajir dan pemangkasan tunas lateral pada parameter jumlah buah per petak.

Model ajir tidak berpengaruh nyata terhadap jumlah buah per petak tetapi data pada Tabel 8. menunjukkan bahwa buah per petak dari tanaman yang diberikan ajir segitiga cenderung lebih banyak sedangkan buah paling sedikit adalah buah per petak dari tanaman yang diberikan ajir pagar. Pemangkasan tunas lateral juga tidak berpengaruh nyata pada jumlah buah per petak dan buah per petak pada tanaman yang dipangkas cenderung lebih banyak dibandingkan tanpa dipangkas.

\section{Tabel 8. Jumlah Buah Per Petak}

\begin{tabular}{|c|c|c|c|}
\hline \multirow{2}{*}{ Model Ajir } & \multicolumn{2}{|c|}{ Pemangkasan Tunas Lateral } & \multirow{2}{*}{ Rerata } \\
\hline & Tanpa Pangkas & Pangkas & \\
\hline Tunggal & $1.038 .314 \mathrm{a}$ & $986.626 \mathrm{a}$ & $1.012 .470 \mathrm{a}$ \\
\hline Pagar & $980.226 \mathrm{a}$ & $809.742 \mathrm{a}$ & $894.984 \mathrm{a}$ \\
\hline Segitiga & $1.013 .448 \mathrm{a}$ & $1.338 .474 \mathrm{a}$ & $1.175 .961 \mathrm{a}$ \\
\hline Rerata & $1.010 .662 \mathrm{a}$ & $1.044 .947 \mathrm{a}$ & $(-)$ \\
\hline Keterangan : & $\begin{array}{l}\text { Angka pada baris dan ko } \\
\text { tidak berbeda nyata men } \\
\text { interaksi antar faktor }\end{array}$ & $\begin{array}{l}\text { g diikuti denga } \\
\text { MRT } \alpha 5 \% \text {. }\end{array}$ & $\begin{array}{l}\text { uf yang sama } \\
\text { Tidak terjadi }\end{array}$ \\
\hline
\end{tabular}

\subsection{Berat Buah Per Petak}

Berat buah per petak meningkat dari panen pertama hingga panen terakhir. Hasil analisis sidik ragam (anova) menunjukkan bahwa tidak terjadi interaksi antara model ajir dan pemangkasan tunas lateral pada parameter berat buah per petak.

\section{Tabel 9. Berat Buah Per Petak (t/ha)}

\begin{tabular}{|c|c|c|c|c|}
\hline \multirow{2}{*}{$\begin{array}{c}\text { Waktu } \\
\text { Pengamatan }\end{array}$} & \multirow{2}{*}{ Model Ajir } & \multicolumn{2}{|c|}{ Pemangkasan Tunas Lateral } & \multirow{2}{*}{ Rerata } \\
\hline & & Tanpa Pangkas & Pangkas & \\
\hline \multirow{4}{*}{ Panen I } & Tunggal & $4,51 \mathrm{a}$ & $2,70 \mathrm{a}$ & $3,61 \mathrm{a}$ \\
\hline & Pagar & $4,15 \mathrm{a}$ & $4,31 \mathrm{a}$ & $4,23 \mathrm{a}$ \\
\hline & Segitiga & $4,16 \mathrm{a}$ & $4,47 \mathrm{a}$ & $4,32 \mathrm{a}$ \\
\hline & Rerata & $4,27 \mathrm{a}$ & $3,83 \mathrm{a}$ & $(-)$ \\
\hline \multirow{4}{*}{ Panen II } & Tunggal & $15,26 \mathrm{a}$ & $11,07 \mathrm{a}$ & $13,17 \mathrm{a}$ \\
\hline & Pagar & $13,28 \mathrm{a}$ & $13,35 \mathrm{a}$ & $13,32 \mathrm{a}$ \\
\hline & Segitiga & $10,88 \mathrm{a}$ & $12,11 \mathrm{a}$ & $11,49 \mathrm{a}$ \\
\hline & Rerata & $13,69 \mathrm{a}$ & $11,66 \mathrm{a}$ & $(-)$ \\
\hline \multirow{4}{*}{ Panen III } & Tunggal & $22,54 \mathrm{a}$ & $18,43 \mathrm{a}$ & $20,48 \mathrm{a}$ \\
\hline & Pagar & $23,09 \mathrm{a}$ & $25,42 \mathrm{a}$ & $24,25 \mathrm{a}$ \\
\hline & Segitiga & $20,99 \mathrm{a}$ & $19,97 \mathrm{a}$ & $20,48 \mathrm{a}$ \\
\hline & Rerata & $22,21 \mathrm{a}$ & $21,27 \mathrm{a}$ & $(-)$ \\
\hline \multirow{4}{*}{ Total Panen } & Tunggal & $42,31 \mathrm{a}$ & $32,20 \mathrm{a}$ & $37,26 \mathrm{a}$ \\
\hline & Pagar & $40,52 \mathrm{a}$ & $43,08 \mathrm{a}$ & $41,80 \mathrm{a}$ \\
\hline & Segitiga & $36,03 \mathrm{a}$ & $36,55 \mathrm{a}$ & $36,29 \mathrm{a}$ \\
\hline & Rerata & $39,62 \mathrm{a}$ & $37,28 \mathrm{a}$ & $(-)$ \\
\hline
\end{tabular}

Keterangan: Angka pada baris dan kolom yang diikuti dengan huruf yang sama tidak berbeda nyata menurut uji DMRT $\alpha 5 \%$. ( - ) : Tidak terjadi interaksi antar faktor

Model ajir tidak berpengaruh nyata pada pengamatan berat buah per petak setiap kali panen. Pada panen I model ajir segitiga memberikan berat buah per petak yang cenderung lebih berat dan model ajir tunggal memberikan berat 
buah per petak paling ringan. Saat panen II ajir model pagar cenderung memberikan buah setiap petak terberat sedangkan model ajir segitiga memberikan berat buah paling ringan, namun pada saat panen III model ajir pagar memberikan berat buah per petak yang cenderung lebih berat dan model ajir tunggal memberikan buah setiap petak yang paling ringan. Total panen menunjukkan ajir model pagar tetap cenderung memberikan buah setiap petak terberat sedangkan model ajir segitiga memberikan berat buah paling ringan.

Pemangkasan tunas lateral tidak berpengaruh nyata pada berat buah per petak tetapi pada Tabel 9. dapat diketahui bahwa perlakuan tanpa pangkas memberikan buah setiap petak yang cenderung lebih berat dibanding perlakuan pangkas.

\subsection{Berat Segar Berangkasan}

Hasil sidik ragam (anova) menunjukkan bahwa tidak terjadi interaksi antar model ajir dan pemangkasan tunas lateral pada parameter berat segar berangkasan.

Model ajir tidak berpengaruh nyata terhadap berat segar berangkasan tetapi data pada Tabel 10. menunjukkan bahwa berangkasan dari tanaman yang diberikan ajir segitiga cenderung lebih berat dibandingkan berat segar berangkasan dari tanaman yang diberikan ajir tunggal dan ajir pagar. Pemangkasan tunas lateral juga tidak berpengaruh nyata pada berat segar berangkasan dimana kedua perlakuan memberikan berangkasan segar yang sama berat.

$\underline{\text { Tabel 10. Berat Segar Berangkasan (t/ha) }}$

\begin{tabular}{cccc}
\hline \multirow{2}{*}{ Model Ajir } & \multicolumn{2}{c}{ Pemangkasan Tunas Lateral } & \multirow{2}{*}{ Rerata } \\
\cline { 2 - 3 } & Tanpa Pangkas & Pangkas & \\
\hline Tunggal & $12,7 \mathrm{a}$ & $11,7 \mathrm{a}$ & $12,2 \mathrm{a}$ \\
Pagar & $12,0 \mathrm{a}$ & $12,4 \mathrm{a}$ & $12,2 \mathrm{a}$ \\
Segitiga & $12,0 \mathrm{a}$ & $12,7 \mathrm{a}$ & $12,4 \mathrm{a}$ \\
\hline Rerata & $12,3 \mathrm{a}$ & $12,3 \mathrm{a}$ & $(-)$ \\
\hline Keterangan : & Angka pada baris dan kolom yang diikuti dengan huruf yang sama \\
& tidak berbeda nyata menurut uji DMRT $\alpha$ 5\%. ( - ) : Tidak terjadi \\
& interaksi antar faktor
\end{tabular}

\subsection{Berat Kering Berangkasan}

Hasil sidik ragam (anova) menunjukkan bahwa tidak terjadi interaksi antar model ajir dan pemangkasan tunas lateral pada parameter berat kering berangkasan.

Model ajir tidak berpengaruh nyata terhadap berat kering berangkasan tetapi data pada Tabel 11. menunjukkan bahwa berangkasan kering dari tanaman yang diberikan ajir segitiga cenderung lebih berat sedangkan berangkasan kering paling ringan adalah berangkasan kering dari tanaman yang diberikan ajir tunggal. Pemangkasan tunas lateral juga tidak berpengaruh nyata pada berat kering berangkasan dan berangkasan kering dari tanaman yang dipangkas cenderung lebih berat dibandingkan tanpa dipangkas.

Tabel 11. Berat Kering Berangkasan (t/ha)

\begin{tabular}{cccc}
\hline \multirow{2}{*}{ Model Ajir } & \multicolumn{2}{c}{ Pemangkasan Tunas Lateral } & \multirow{2}{*}{ Rerata } \\
\cline { 2 - 3 } & Tanpa Pangkas & Pangkas & \\
\hline Tunggal & $6,3 \mathrm{a}$ & $5,9 \mathrm{a}$ & $6,2 \mathrm{a}$ \\
Pagar & $6,9 \mathrm{a}$ & $7,2 \mathrm{a}$ & $7,0 \mathrm{a}$ \\
Segitiga & $6,3 \mathrm{a}$ & $7,9 \mathrm{a}$ & $7,1 \mathrm{a}$ \\
\hline Rerata & $6,5 \mathrm{a}$ & $7,0 \mathrm{a}$ & $(-)$ \\
\hline Keterangan : & Angka pada baris dan kolom yang diikuti dengan huruf yang sama \\
& tidak berbeda nyata menurut uji DMRT $\alpha$ 5\%. ( - ) : Tidak terjadi \\
& interaksi antar faktor
\end{tabular}

\subsection{Indeks Panen}

Hasil sidik ragam (anova) menunjukkan bahwa tidak terjadi interaksi antar model ajir dan pemangkasan tunas lateral pada parameter indeks panen.

Tabel 12. Indeks Panen (\%)

\begin{tabular}{|c|c|c|c|}
\hline \multirow{2}{*}{ Model Ajir } & \multicolumn{2}{|c|}{ Pemangkasan Tunas Lateral } & \multirow{2}{*}{ Rerata } \\
\hline & Tanpa Pangkas & Pangkas & \\
\hline Tunggal & $76,7 \mathrm{a}$ & $77,5 \mathrm{a}$ & $77,1 \mathrm{a}$ \\
\hline Pagar & $74,8 \mathrm{a}$ & $72,2 \mathrm{a}$ & $73,5 \mathrm{a}$ \\
\hline Segitiga & $78,3 \mathrm{a}$ & 73,9 a & $76,1 \mathrm{a}$ \\
\hline Rerata & $76,6 \mathrm{a}$ & $74,5 \mathrm{a}$ & $(-)$ \\
\hline Keterangan : & $\begin{array}{l}\text { Angka pada baris dan kol } \\
\text { tidak berbeda nyata menu } \\
\text { interaksi antar faktor }\end{array}$ & $\begin{array}{l}\text { liikuti de } \\
\text { IRT } \alpha 5 \%\end{array}$ & $\begin{array}{l}\text { f yang } \\
\text { Tidak }\end{array}$ \\
\hline
\end{tabular}

Model ajir tidak berpengaruh nyata terhadap indeks panen tetapi data pada Tabel 12. menunjukkan bahwa indeks panen dari tanaman yang diberikan ajir tunggal cenderung lebih tinggi sedangkan indeks panen paling rendah adalah indeks panen dari tanaman yang diberikan ajir pagar. Pemangkasan tunas lateral juga tidak berpengaruh nyata pada indeks panen dan indeks panen dari tanaman yang tidak dipangkas cenderung lebih tinggi dibandingkan yang dipangkas.

\subsection{Pembahasan}

Model ajir pagar memberikan hasil tomat berupa berat buah per petak total panen paling berat. Hal ini terjadi karena pada panen kedua dan panen ketiga, perlakuan ajir pagar juga menghasilkan buah yang paling berat meskipun pada panen pertama perlakuan ajir pagar menghasilkan buah per petak yang tidak terlalu berat. Hasil tertinggi ini dicapai karena perlakuan ini memberikan hasil berupa buah yang lebih besar walaupun jumlah buahnya sedikit baik setiap tanamannya maupun jumlah buah per petak. Pemberian ajir pagar juga memberikan pertumbuhan tanaman berupa batang yang lebih besar walaupun cenderung pendek dengan daun yang lebih sempit. Hal ini menunjukkan bahwa fotosintat yang dihasilkan lebih banyak ditranslokasikan untuk pertumbuhan generatif berupa pembentukan buah yang lebih besar dibandingkan dengan pertumbuhan vegetatif.

Diduga bahwa ajir pagar memungkinkan tajuk tanaman tersebar lebih terbuka sehingga cahaya lebih merata terdistiribusi pada permukaan daun selanjutnya lebih banyak organ tanaman yang menjalankan proses fotosintesis. Menurut Stewart et al., (2003), susunan daun di dalam tajuk lebih menentukan serapan cahaya dibanding indeks luas daun. Jumlah, sebaran dan sudut daun pada suatu tajuk tanaman menentukan serapan dan sebaran cahaya matahari sehingga mempengaruhi fotosintesis dan hasil tanaman. Faktor yang berpengaruh antara lain populasi, jarak antar barisan dan bentuk tajuk akan mempengaruhi sebaran daun. Sebaran daun dalam tajuk mengakibatkan cahaya yang diterima setiap helai daun tidak sama. Egli (1999) menyatakan bahwa produktivitas (yield) tanaman dibatasi oleh aktivitas fotosintesis source atau kemampuan sink untuk menggunakan asimilat yang dihasilkan source. Distribusi asimilat menjadi penting dalam menentukan hasil akhir tanaman.

Tomat yang tidak dipangkas memberikan hasil berupa berat buah per petak total panen paling berat karena pada setiap kali panen tomat yang tunas lateralnya tidak dipangkas selalu menghasilkan buah per petak yang paling berat. Perlakuan ini walaupun memberikan buah dengan jumlah yang lebih sedikit setiap petaknya tetapi buah yang dihasilkan lebih besar dan lebih berat. Hasil tinggi yang dicapai disebabkan karena pembentukan organ vegetatif tidak terlalu dominan berupa tanaman yang lebih pendek dan berbatang kecil.

Secara kuantitatif pemangkasan tunas lateral menghasilkan buah yang lebih banyak tetapi terjadi penurunan kualitas buah dimana buah yang terbentuk berukuran lebih kecil dan lebih ringan, meski demikian penurunan yang terjadi tidak signifikan mempengaruhi hasil pada tanaman tomat varietas Lentana.

\section{Simpulan}

Dari analisis hasil dan pembahasan yang dilakukan maka dapat disimpulkan beberapa hal sebagai berikut:

a. Interaksi antara model ajir dan pemangkasan tunas lateral tidak terjadi pada semua parameter yang diamati.

b. Model ajir hanya berpengaruh nyata pada parameter diameter batang 42 HST sedangkan pemangkasan tunas lateral tidak berpengaruh nyata pada semua parameter.

c. Pemberian ajir model pagar memberikan hasil total panen tertinggi yakni 39,99 t/ha dibandingkan ajir model tunggal dan segitiga. Perlakuan tanpa pangkas memberikan hasil total panen tertinggi yaitu 41,28 t/ha dibandingkan perlakuan pemangkasan tunas lateral.

\section{Pustaka}

BPS TTU. 2014. Statistik Pertanian Kabupaten Timor Tengah Utara. Kefamenanu

Egli, D.B. 1999. Variation in leaf starch and sink limitation during seed filling in soybean. Crop Sci. 39:1361-1368.

Fitriani Emi. 2012. Untung Berlipat Budidaya Tomat. Yogyakarta.

Hanindita. 2008. Peluang Usaha di Bidang Hortikultura, Khususnya Tomat. Yogyakarta.

Nasir. 2003. Metode Penelitian. Ghalia Indonesia, Jakarta.

Pracaya. 1998. Bertanam Tomat. Kanisius. Yogyakarta

Rukmana, R.H. 1994. Tomat Chery. Kanisius (Anggota IKAPI), Yogjakarta.

Setiawan danTrisnawati. 1999. Budidaya Secara Komersial. Penebar Swadaya. Jakarta.

Stewart, D.W., C. Costa., L. M. Dwyer, D. L. Smith, R. I. Hamilton and B. L. Ma. 2003. Canopy Structure, Light Interception, and Photosynthesis in Maize. Agron. J. 95:1465-1474.

Susanto dan Saneto. 1994. Komposisi Zat Gisi Buah Tomat. Jakarta 